\title{
Clearance rates of Oikopleura in cold coastal Newfoundland waters: a predictive model and its trophodynamic implications
}

\author{
Roy Knoechel, Deborah Steel-Flynn* \\ Department of Biology, Memorial University of Newfoundland, St. John's, Newfoundland, Canada A1B 3X9
}

\begin{abstract}
Oikopleura vanhoeffeni inhabiting cold coastal Newfoundland waters are much larger than the extensively studied warm water species, $O$. dioica; nevertheless they possess fine-meshed feeding filters capable of retaining the nanoplankton that dominate the water column throughout much. of the year. Total clearance rates were determined using radioactively labelled algae presented to individuals in feeding chambers in situ over a seasonal range of ambient water temperatures and food concentrations. Stepwise multiple regression analysis indicated that oikopleurid size explained $46 \%$ of the variance in clearance rate. An additional $10 \%$ of the variation was explained by the ambient biomass concentrations of chain-forming diatoms and of picoplankton $(<2 \mu \mathrm{m}$ in diameter), consistent with a filter-clogging interpretation. Water temperature was not a significant variable in the regression model and its coefficient was negative, indicating that clearing rates were highest at the near $0^{\circ} \mathrm{C}$ temperatures characteristic of the spring bloom, a period when bacterial activity is suppressed. Water column clearing rates attributable to Oikopleura populations were comparable to those calculated for the copepod community based on published data. The large size and conspicuous pigmentation of $O$. vanhoeffeni should make them particularly susceptible to visually feeding planktivores and they may thus constitute an important link in the food chain supporting a large commercial fishery.
\end{abstract}

\section{INTRODUCTION}

Members of the family Oikopleuridae feed within a roughly spherical mucous 'house' (Lohmann 1899) containing 2 sets of filters (Fig. 1). Sinusoidal movement of the oikopleurid's muscular tail draws water into the house through the coarse incurrent filters that exclude large particles, and then pumps the water through finer feeding filters where sieving action results in a concentrated food suspension. This suspension is then further concentrated by a mucous pharyngeal net which conveys food particles into the mouth (Deibel 1986). These animals are able to concentrate plankton too small for efficient consumption by setose-appendage feeding copepods and may constitute a key pathway of energy flow from nano and picoplankton to higher trophic levels. The phytoplankton biomass of cold coastal Newfoundland waters is dominated by small nano-

- Present address: Marine Sciences Research Laboratory, Memorial University of Newfoundland, St. John's, Newfoundland, Canada A1C 5S7

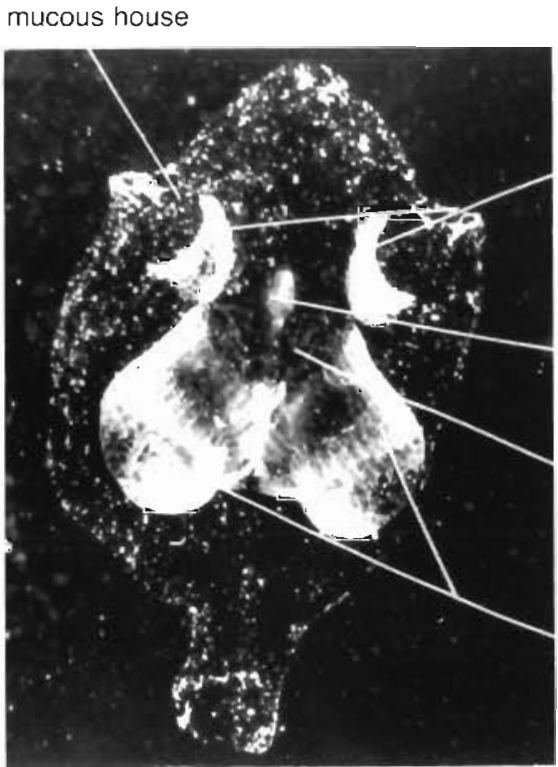

incurrent filters

trunk

tail

feeding filters

Fig. 1. Oikopleura vanhoeffeni. Underwater photograph of an individual within its gelatinous house (photo courtesy of R. Hooper) 
plankton forms throughout most of the year and these waters support a major fishery. Annual landings of pelagic and groundfish along the east coast of insular Newfoundland averaged 258000 tonnes during the 1985 to 1987 period (Canadian Dept Fish. Oceans catch statistics for NAFO divisions $3 \mathrm{~K}$ and $3 \mathrm{~L}$ ). The role of appendicularians in fishery production is little known; however, they have been identified as a principle diet item of larval plaice in the North Sea (Shelbourne 1962). Oikopleura vanhoeffeni, an appendicularian common in Newfoundland waters, is much larger than the warm water species that have been most frequently studied and it should thus be particularly susceptible to visually feeding planktivores. It also has the largest incurrent filter pore size reported for any appendicularian (ca $169 \times 88 \mu \mathrm{m}$; Deibel \& Turner 1985) and is capable of ingesting some of the larger phytoplankton including silicoflagellates, dinoflagellates and even some chain-forming diatoms (Deibel \& Turner 1985).

Previous appendicularian feeding studies have been limited to 2 warm water species, Oikopleura dioica (Paffenhöfer 1976, Alldredge 1981, King 1981) and Stegasoma magnum (Alldredge 1981), and have been conducted over brief field periods encompassing little variation in environmental parameters such as temperature and seston concentration. The object of the present study was to determine in situ total clearance rates for these large, cold ocean appendicularians over a seasonal period and to then investigate, using multiple linear regression analysis, the amount of variability in the clearance rate data that could be attributed to the properties of the organism (such as size) and to environmental parameters. The resulting clearance rate model is then combined with Oikopleura population densities to provide insights into the potential feeding impact of these animals on plankton populations and into their role in energy transfer in cold ocean waters.

\section{MATERIALS AND METHODS}

In situ feeding studies were conducted from March to July 1983 and from April to July 1984 in Logy Bay $\left(47^{\circ} 37^{\prime} \mathrm{N}, 52^{\circ} 40^{\prime \prime} \mathrm{W}\right)$ near St. John's on the Avalon Peninsula, Newfoundland, Canada. Logy Bay is broadly exposed to the Atlantic Ocean and is characterized by a core of inshore Labrador Current water $\left(-1.7\right.$ to $\left.2.0^{\circ} \mathrm{C}, 32.6 \%\right)$ at depth, and a seasonal, warmer $\left(6\right.$ to $12{ }^{\circ} \mathrm{C}, 31.0 \%$ o) surface layer composed of mixed Labrador Current and coastal waters that is greatly affected by wind speed and direction (Kendaris 1980). Templeman (1966) proposed that coastal water mass exchange occurs when strong offshore winds displace the warmer surface layer causing the deeper cold water to upwell in inshore areas. Onshore winds have the reverse effect of thickening the mixed surface layer while the bottom layer is pushed offshore. Changes in the density and distribution of oikopleurid taxa have been observed to coincide with the movement of these water masses within the bay (Thompson. \& Frost 1936, Udvardy 1954, Deibel \& Steel-Flynn unpubl.). In the present study, oikopleurids captured at water temperatures near or below $0^{\circ} \mathrm{C}$ (characteristic of pure Labrador Current water) had red-pigmented tails ranging in length from 8 to $20 \mathrm{~mm}$, characteristic of Oikopleura vanhoeffeni. Average-sized individuals (13 $\mathrm{mm}$ tail length) had house diameters ranging from ca 40 to $60 \mathrm{~mm}$. At warmer water temperatures later in the season, the oikopleurids lacked the red pigmentation and tail lengths were usually less than $4 \mathrm{~mm}$. These individuals were probably juvenile $O$. vanhoeffeni but could possibly have been O. labradoriensis which is a smaller, but otherwise morphologically similar, species. Given the difficulty of differentiating between species for smaller individuals (Davis 1982, 1986) we herein refer to our animals collectively as Oikopleura or 'oikopleurids', with the understanding that the great majority of the experimental specimens were definitely $O$. vanhoeffeni. A much smaller appendicularian, Fritillaria borealis, also occurs in coastal Newfoundland waters (Davis 1982, 1986) but is not considered here.

Water samples were collected and preserved with Lugol's solution for analysis of the biomass and size spectrum of ambient phytoplankton and large bacteria. Cell numbers and sizes were determined by microscopic examination (phase contrast, $480 \times$ ) of replicate permanent mount slides (Knoechel \& Kalff 1976). Cell volumes were calculated from formulae for simple geometric solids, converted to wet weight biomass (mg $\mathrm{m}^{-3}$ ) using a specific gravity of 1.0 , and then summarized into 5 size categories corresponding to cells with maximum dimensions of $<2 \mu \mathrm{m}, 2-5 \mu \mathrm{m}, 5-30 \mu \mathrm{m}$, $>30 \mu \mathrm{m}$ unicellular centric diatoms and $>30 \mu \mathrm{m}$ chainforming diatoms (primarily species of Nitzschia, Chaetoceros and Thalassiosira). Zooplankton net hauls (125 $\mu \mathrm{m}$ mesh) were taken to ascertain ambient oikopleurid population density and size distribution on a number of dates between July 1983 and July 1984.

In addition to the particles actually ingested, appendicularians collect food particles both on the filters and on the external house surface which together can serve as a carbon-rich food source for other organisms (Alldredge 1975, 1976, 1977, 1981). Thus, when examining the potential trophic impact and importance of these zooplankton, most authors (e.g. Paffenhöfer 1976, Alldredge 1981, King 1981) determine total clearance rate which includes particle collection by both the oikopleurid and the house combined. In the current study, total clearance rates were determined from in situ feed- 
ing trials conducted on individuals captured by SCUBA divers in 1 or 21 grazing chambers (Fig. 2). The chambers were stoppered and a 1 to $2 \mathrm{ml}$ suspension of ${ }^{14} \mathrm{C}$ labelled Scenedesmus quadricauda was added (ca

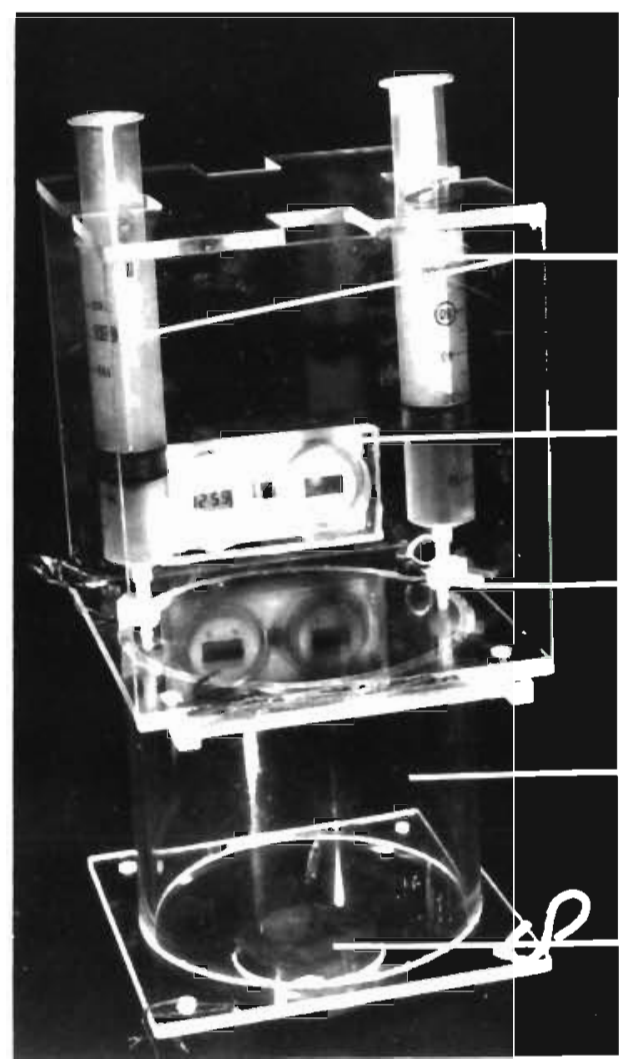

$50 \mathrm{ml}$ syringes

clocks

3-way valve

grazing chamber

rubber stopper

Fig. 2. Experimental feeding chamber

$4 \mu \mathrm{m}$ in diameter: see Holtby \& Knoechel 1981 for labelling procedures). The diver added the food suspension through a 3-way valve (Fig. 2) and then alternately filled the attached $50 \mathrm{ml}$ syringes to effect mixing within the grazing chamber. The chambers were suspended at the depth of animal collection (5 to $7 \mathrm{~m}$ ) for a $10 \mathrm{~min}$ feeding period. This interval was shorter than the gut passage time (pers. obs.). The feeding trial was aborted if the oikopleurid jettisoned its house.

The experimental chamber was hauled to the surface near the end of the feeding period, which was terminated by gently prodding the oikopleurid from its house. An automatic pipette with an enlarged bore (ca $0.8 \mathrm{~cm}$ ) was then used to separately collect the oikopleurid and the house which were placed individually in pre-weighed scintillation vials. An additional $4 \mathrm{ml}$ 'food water' sample was taken from the grazing chamber to determine the radioactivity of the food suspension in the chamber. Acid Lugol's iodine was used to preserve all samples because this preservative has been found to minimize the loss of radioactivity from zooplankton fed ${ }^{14} \mathrm{C}$-labelled algae (Holtby \& Knoechel 1981).

The preserved specimens were removed from the vials in the laboratory and tail lengths were measured to the nearest $0.01 \mathrm{~mm}$ using a Bausch-Lomb projection microscope and Zeiss digitizer. Previous researchers (Alldredge 1975, 1981, King 1981) have used trunk length (Fig. 1) or animal weight (Paffenhöfer 1973, 1976) as a measure of animal size. Trunk length and tail length were highly correlated in the present study (trunk $=[0.238$ tail $]+0.188, r=0.92)$. We used tail length because it is larger than the trunk and thus can be measured with greater precision.

Prior to determination of radioactivity, the specimens were digested overnight at $30^{\circ} \mathrm{C}$ in $1 \mathrm{ml}$ of Protosol (NEN) following which $10 \mathrm{ml}$ of PCS (Amersham) and $5 \mathrm{ml}$ of OCS (Amersham) were added as fluor. After removal of the specimens, each scintillation vial was reweighed to the nearest $0.1 \mathrm{~g}$ to calculate the volume of fluid ('animal water') that had been collected along with the oikopleurid. Ten ml of Aquasure liquid scintillation counting solution (New England Nuclear) was added as fluor to the 3 vials containing the 'animal water', the 'food water', and the oikopleurid house (plus associated water). Counts per minute (cpm) were determined for 10 min or $1 \%$ precision using a Beckman liquid scintillation counter and corrections for efficiency and quenching were made using the external standards ratio method calibrated by internal standardization with ${ }^{14} \mathrm{C}$ labelled toluene. An average of 3 replicate sample counts was used in subsequent calculations.

The ratio of 'food water' radioactivity to that of the 'animal water' should be 1.0 if the added food suspension was homogeneously distributed within the grazing chamber and if there was no loss of activity from the specimen itself following preservation. Only those feeding trials in which these 2 values were within $10 \%$ of each other were retained for further data analysis.

Total clearance rates were calculated using background-corrected disintegrations per minute (dpm) for the oikopleurid, the house and the 'food water'. These total clearance rates represent the volume of water effectively cleared of tracer particles per unit time through the combined collection by both the specimen and the house. They should not be confused with ingestion rates which are measures of mass consumed per unit time by the specimen alone. First, house dpm was calculated as:

$$
\begin{aligned}
& \text { house } \mathrm{dpm}=(\text { house }+ \text { fluid } \mathrm{dpm}) \\
& \quad\left(\mathrm{mls} \text { fluid } \times \text { food water } \mathrm{dpm} \mathrm{ml}^{-1}\right)
\end{aligned}
$$

House dpm thus represents the residual radioactivity due to the particle collection on or in the oikopleurid's house after correcting for the radioactivity of the food in 
the water that was unavoidably collected in the pipette along with the house (see above). Total clearance rate (TCR) was then calculated as

$$
\begin{aligned}
\operatorname{TCR}\left(\mathrm{ml} \mathrm{d}^{-1}\right)= & \frac{\text { animal dpm }+ \text { net house } \mathrm{dpm}}{\text { food } \mathrm{dpm} \mathrm{ml}^{-1}} \times \\
& \frac{1440 \mathrm{~min}^{-1}}{\text { feeding period (min) }}
\end{aligned}
$$

Relationships between total clearance rates and animal tail length, ambient plankton biomass and ambient water temperature were examined using stepwise multiple regression analysis (SPSS ${ }^{\mathrm{x}}$. Nie et al. 1983) on a VAX 1170 operating under VMS. The relationship between clearance rate and tail length is a power function which was linearized by log transformation of the data for entry into the multiple regression model (Knoechel \& Holtby 1986). Plankton biomass data were also log-transformed to normalize their distributions. The data for the centric and chain-forming diatom categories included zero values so these data were transformed as $\log (y+1)$. Residual scatter plots for the clearance rate models were visually examined to evaluate underlying trends in the data and relationship strengths (Hartwig \& Dearing 1979), to ensure that entry of subsequent variables was not the result of undue influence of residual outliers, and to look for non-linear relationships that would not be revealed by linear regression analysis.

\section{RESULTS AND DISCUSSION}

Plankton concentrations in Newfoundland waters are extremely low throughout most of the year. Concentrations on sampling dates ranged from 82 to $1140 \mathrm{mg} \mathrm{m}^{-3}$ (wet weight; Fig. 3) with levels most commonly in the 100 to $200 \mathrm{mg} \mathrm{m}^{-3}$ range. This latter range is equivalent to only 10 to $20 \mu \mathrm{g}$ carbon $\mathrm{l}^{-1}$, assuming carbon content to be ca $10 \%$ of biovolume (Strathmann 1967). Such low carbon levels are typical of oligotrophic oceans. The bulk of the plankton biomass was most frequently in the 2 to $5 \mu \mathrm{m}$ category in 1983, and in the 2 to $5 \mu \mathrm{m}$ category plus the chain-forming diatom category in 1984 (note log scales in figure). Ambient water temperature ranged from -1.2 to $+11.5^{\circ} \mathrm{C}$ during the study period.

One limitation of the radioactive tracer particle technique is that the calculated clearance rates are specific to the size and type of particle used as a tracer. This limitation should not be particularly restrictive in the current study because oikopleurids employ a true porous-filter feeding mechanism. Previous study of mucous-net feeding salps has revealed a very sharp cut-off above which filtering efficiencies remain uniform for a broad range of particle sizes (Harbison \&
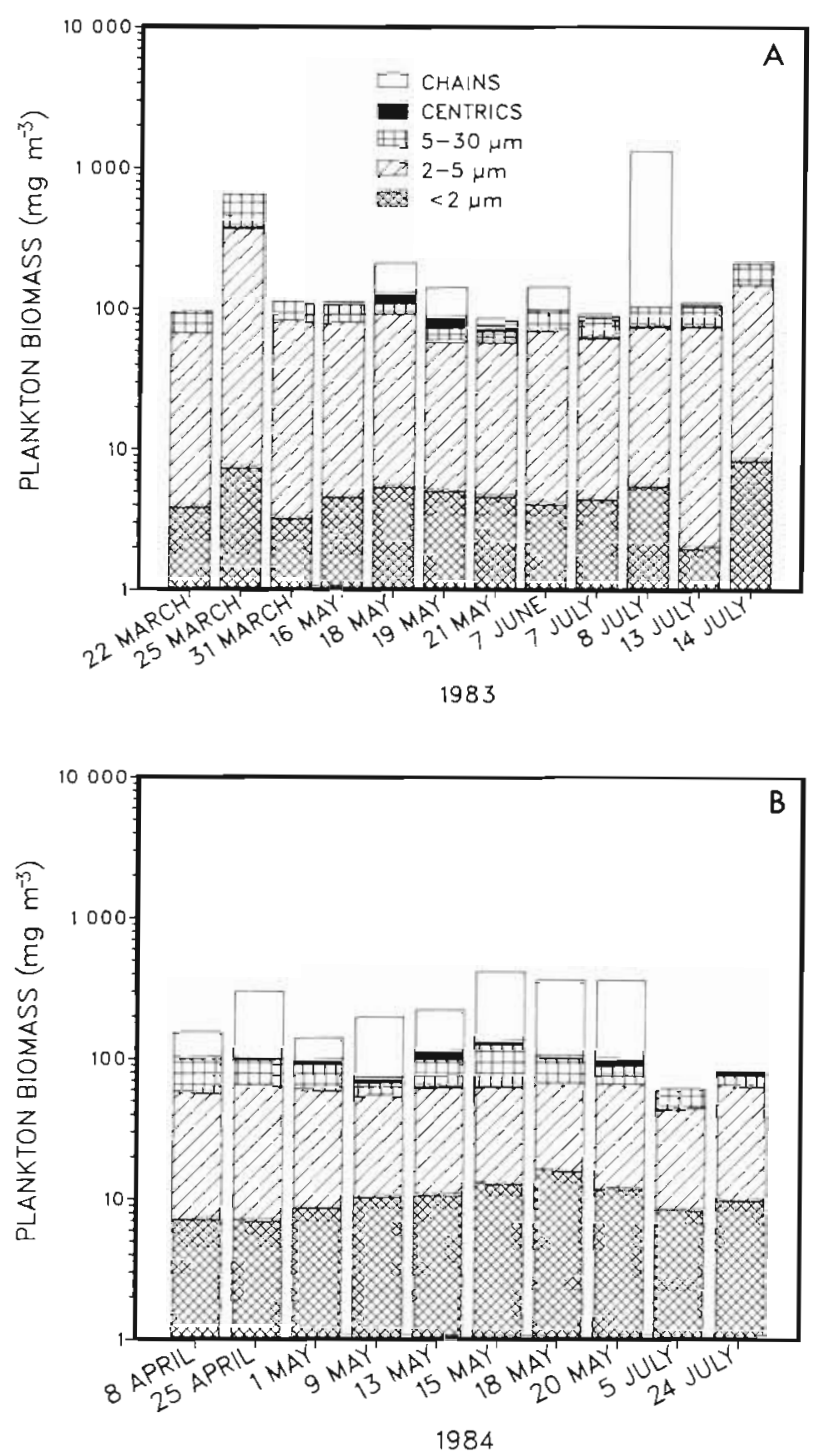

Fig. 3. Plankton biomass and size distribution for sampling dates in (A) 1983 and (B) 1984

McAlister 1979). The presence of the coarse pre-filter in oikopleurids complicates matters by adding an upper cut-off range. It seems reasonable to assume that clearance rates determined using our $4 \mu \mathrm{m}$ tracer particles should be representative of approximately the 1 to 20 um particle size range, considering the pore dimensions of the incurrent and feeding filters (see below). The particle size range actually ingested by the oikopleurid will be modified by the physical characteristics and flow regime of the internal pharyngeal filter, which has been reported to have a pore size larger than that of the house feeding filter (Diebel 1986). Studies are currently underway to determine retention efficiency:particle size relations for Oikopleura vanhoeffeni (D. Deibel pers. comm.). 
Table 1. Oikopleura. Regression models for the prediction of clearance rate from tail length alone (length model) or in concert with plankton biomass variables (full model) or in concert with plankton variables plus temperature (plus temperature). Regression coefficients $(b)$, cumulative correlation coefficients $(r)$, total explained variances $\left(r^{2}\right)$, squared part correlation coefficients (part $r^{2}$ ), and Student's $t$-values are provided.

\begin{tabular}{|c|c|c|c|c|c|}
\hline Variable & $b$ & $r$ & $r^{2}$ & Part $r^{2}$ & $t$ \\
\hline \multicolumn{6}{|l|}{ Length model } \\
\hline Log tail length & 1.578 & 0.678 & 0.460 & 0.460 & 7.61 \\
\hline Constant & 1.354 & & & & 7.81 \\
\hline \multicolumn{6}{|l|}{ Full model } \\
\hline Log tail length & 1.728 & 0.678 & 0.460 & 0.526 & 8.90 \\
\hline Log chain diatom & -0.094 & 0.720 & 0.519 & 0.043 & -2.53 \\
\hline Log $<2 \mu \mathrm{m}$ plankton & -0.473 & 0.746 & 0.556 & 0.038 & -2.36 \\
\hline Constant & 1.680 & & & & 8.54 \\
\hline \multicolumn{6}{|l|}{ Plus temperature } \\
\hline Log tail length & 1.440 & 0.678 & 0.460 & 0.167 & 5.02 \\
\hline Log chain diatom & -0.091 & 0.720 & 0.519 & 0.040 & -2.46 \\
\hline Log $<2 \mu \mathrm{m}$ plankton & -0.461 & 0.746 & 0.556 & 0.036 & -2.32 \\
\hline Temperature & -0.019 & 0.754 & 0.568 & 0.012 & -1.36 \\
\hline Constant & 1.995 & & & & 6.76 \\
\hline
\end{tabular}

Calculated in situ total clearance rates ranged from 33 to $4382 \mathrm{ml}$ ind ${ }^{-1} \mathrm{~d}^{-1}$ for oikopleurids ranging in size from 2.2 to $19.2 \mathrm{~mm}$ tail length (Fig. 4). Nearly half $(46 \%)$ of the variation in clearance rate was explained

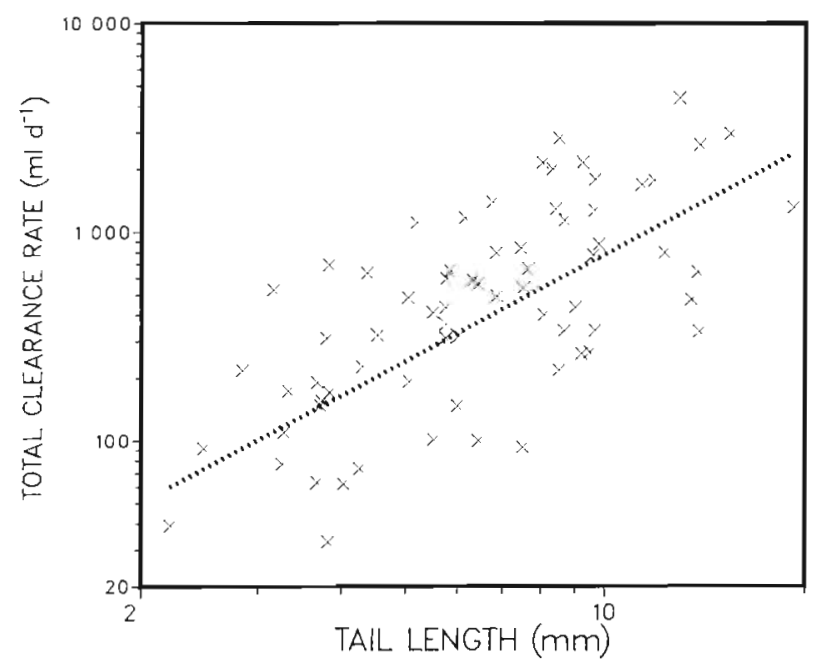

Fig. 4. Oikopleura. Relation between individual clearance rate and tail length

by tail length alone (Table 1 : length model). Expressed as a power equation, the relationship between total clearance rate ( $\mathrm{ml}$ ind..$^{-1} \mathrm{~d}^{-1}$ ) and tail length $(\mathrm{mm})$ was:

$$
\mathrm{TCR}=22.608 \mathrm{~L}^{1.578}
$$

The biomass of chain-forming diatoms and of the $<2 \mu \mathrm{m}$ plankton category subsequently entered the regression model as significant variables (Table 1: full model) and resulted in a final explained variance of
$56 \%$. Simple correlations between each plankton biomass category and the clearing rate:tail length regression residuals are presented in Table 2, which shows clearly the lack of influence of variation in the biomass of intermediate size categories. The negative regression coefficients for the smallest and largest classes

Table 2. Oikopleura. Correlation strengths $(r)$ and significance levels $(p)$ of relationships between plankton biomass size fractions (log-transformed) and the residuals of the clearing rate:tail length regression

\begin{tabular}{|lrc|}
\hline Size fraction & $r$ & $p$ \\
\hline$<2 \mu \mathrm{m}$ & -0.235 & 0.009 \\
$2-5 \mu \mathrm{m}$ & 0.016 & 0.862 \\
$5-30 \mu \mathrm{m}^{\mathrm{d}}$ & 0.007 & 0.942 \\
Centric diatoms & -0.151 & 0.127 \\
Chain diatoms & -0.244 & 0.006 \\
Total plankton & -0.162 & 0.070 \\
a Although stated as 5-30 & $\mu \mathrm{m}$ to maintain range continuity, \\
nearly all biomass was within the 5-10 $\mu \mathrm{m}$ size range & \\
\hline
\end{tabular}

(Table 1: full model) indicate that an increase in biomass of either size category had an inhibiting effect on clearance rate, an effect not previously noted in other oikopleurid studies but consistent with satiation or saturation effects commonly observed in 'filter feeding' crustaceans (Frost 1972, Geller 1975). We regard satiation as unlikely given the generally low plankton biomass present, particularly in the $<2 \mu \mathrm{m}$ category (Fig. 3). Geller (1975) observed constant cladoceran filtering rates below food concentrations of 1000 to $5000 \mathrm{mg} \mathrm{m}^{-3}$ and Frost (1972) observed constant 
copepod feeding rates below concentrations of 8000 $\mathrm{mg} \mathrm{m} \mathrm{m}^{-3}$. Huntley (1981) found no evidence of saturated feeding in his studies of copepods in the Labrador Sea even at the height of the spring bloom. We think the negative effects observed in the current study for particles at the opposite ends of the food size spectrum are more consistent with a filter clogging interpretation. The chain-forming diatoms are the appropriate size to clog the coarse incurrent filter (pore size $169 \times 88 \mu \mathrm{m}$ : Deibel \& Turner 1985) while the $<2$ um particles could become lodged in the feeding filters (pore size $1.04 \times 0.22 \mu \mathrm{m}$ : Deibel et al. 1985). The fact that the absolute magnitude of the negative plankton coefficients (Table 1 ) is less than 1.0 indicates that the clearance rate is declining less rapidly than the plankton biomass is increasing. This means that ingestion rates (mass per unit time) should still be increasing even as clearance rates decline.

Total clearance rate was also negatively correlated with temperature $(r=-0.592, p<0.005)$; however, multiple regression analysis suggested that this trend resulted largely from an inverse correlation between temperature and tail length $(r=-0.738, p<0.001)$; temperature was not a significant factor $(r=-0.201$, $p=0.13$ ) in the multiple regression once tail length had entered the model. One way to evaluate the relative importance of 2 confounded variables in a multiple regression model is to compare the squared part correlation coefficients. These coefficients represent the unique contribution to explained variance resulting from the addition of the variable in question to a model that already contains all of the other variables (Norusis 1985). Inspection of these coefficients ('plus temperature' model in Table 1) reveals that temperature contributes very little unique variance $(1.2 \%)$.

The fact that temperature did not have a significant independent effect, and that what effect there was had a negative coefficient, has important implications for the ecology of these animals. The negative coefficient means that clearing rates were maximal at the lowest temperatures we encountered $\left(-1.2^{\circ} \mathrm{C}\right)$. Oikopleura is thus well adapted to exploit the spring bloom that typically occurs during April and May when water temperature ranges from -1 to $+2{ }^{\circ} \mathrm{C}$ (Pomeroy \& Deibel 1986). Although the bacteria present at this time can be characterized as psychrophiles (Gow \& Mills 1984), peak growth and specific heterotrophic activity is achieved in the 5 to $12{ }^{\circ} \mathrm{C}$ range (Gow \& Mills 1984, Powell et al. 1987). Pomeroy \& Deibel (1986) have hypothesized that bacterial inhibition at low spring bloom temperatures leaves a larger proportion of the primary production available to the food chain supporting the fishery than would be the case in warmer waters. The ability of Oikopleura to clear particles maximally at low temperature suggests that they are well suited to tap this resource and make it available to higher trophic levels.

The proportion of total clearance rate variance explained by animal size (46\%) is considerably lower than that observed for a wide size range of freshwater cladocerans $(92 \%)$ in similar feeding studies (Knoechel \& Holtby 1986), indicating that oikopleurids seem to be inherently much more variable over the short feeding intervals employed. We evaluated the short-term variability in animal activity through direct observation of the tail movement. This was facilitated by the large size of Oikopleura vanhoeffeni and its bright tail coloration. Tail-beat activity should affect the clearance rate because it is the movement of the tail which drives water flow through the house. Activity was qualitatively observed to vary considerably between sampling days and also between individuals on the same sampling day, both under experimental (in feeding chambers) and natural conditions. The activity of individuals also varied considerably during the feeding trials. On one sampling date, the number of tailbeats were recorded for each minute of the 10 min feeding period for each of 5 specimens. The number of tailbeats recorded per minute ranged from 0 to 110 and coefficients of variation calculated for individuals ranged from 9.6 to $112.1 \%$. The most active individuals displayed the least variability over the 10 min feeding period. These data suggest that longer feeding trials should reduce the variance in measured individual total clearance rates. In the present study, we purposely kept the feeding trials short so as to not exceed the gut passage time. This might not be necessary in future studies, given the observation that fecal pellets are retained within the appendicularian house and should therefore still be collectable at the end of the experiment.

The strength of correlation between clearance rate and tail length noted herein (0.68) is within the range reported in previous studies of oikopleurids. Interestingly, it appears that the strength of correlation varies inversely with the number of days over which the experiments were conducted (Table 3). For example, Alldredge (1981) reported a correlation coefficient of 0.66 between clearance rate and body size for Oikopleura dioica over an $11 \mathrm{~d}$ sampling period, whereas reanalysis of her data produces correlations as high as 0.99 for single dates (Table 3). Conversely, correlations reported by Alldredge (1981) for Stegasoma magnum on 3 individual sampling dates were very strong $(>0.8)$ but when the data are combined and reanalyzed the correlation is reduced to only 0.27 (Table 3 ). Selecting data from the current study for 2 nearly contiguous dates produced a much higher correlation between clearance rate and tail length than that for the entire study period ( $r=0.90$ vs 0.68 ; Table 3 ). These observations suggest that the animals may be responding to 
Table 3. Comparison of strength of correlations $(r)$ reported for total clearance rate $\left(\mathrm{ml} \mathrm{ind}^{-1} \mathrm{~d}^{-1}\right)$ with trunk length (Alldredge 1981 ) or tail length (present study) over different length sampling periods ( $n$ : number of observations)

\begin{tabular}{|c|c|c|c|c|}
\hline Source & Species & Days & $n$ & $r$ \\
\hline $\begin{array}{c}\text { Alldredge } \\
\text { (1981) }\end{array}$ & Oikopleura dioica & $\begin{array}{ll}1 & \text { (9 Jul) } \\
1 & \text { (12 Jul) } \\
1 & (14 \text { Jul) } \\
1 & \text { (20 Jul) } \\
4 & \text { (above days } \\
& \text { combined) }\end{array}$ & $\begin{array}{r}9 \\
8 \\
4 \\
7 \\
28\end{array}$ & $\begin{array}{l}0.53^{\mathrm{a}} \\
0.99^{\mathrm{a}} \\
0.82^{\mathrm{a}} \\
0.67^{\mathrm{a}} \\
0.66\end{array}$ \\
\hline $\begin{array}{c}\text { Alldredge } \\
\text { (1981) }\end{array}$ & Stegasoma magnum & $\begin{array}{ll}1 & \text { (22 Jul) } \\
1 & \text { (23 Jul) } \\
1 & \text { (26 Jul) } \\
3 & \text { (above days } \\
& \text { combined) }\end{array}$ & $\begin{array}{r}8 \\
7 \\
7 \\
22\end{array}$ & $\begin{array}{l}0.84 \\
0.93 \\
0.93 \\
0.27^{\circ}\end{array}$ \\
\hline $\begin{array}{l}\text { This study } \\
\text { a Recalcula }\end{array}$ & $\begin{array}{l}\text { Oikopleura vanhoeffeni } \\
\text { zed data taken from origir }\end{array}$ & $\begin{array}{l}2 \text { (19, } 21 \text { May 1983) } \\
22 \text { (over a } 2 \text { yr period) } \\
\text { ures }\end{array}$ & $\begin{array}{l}10 \\
70\end{array}$ & $\begin{array}{l}0.90 \\
0.68\end{array}$ \\
\hline
\end{tabular}

environmental variables we have not yet considered or that they may be displaying innate seasonal variation. In any case, it is obvious that extrapolation from single dates to longer time periods (and vice versa) must be done with caution. Calculation of daily clearance rates from short-term feeding studies also implicitly assumes that there is no diurnal pattern, an assumption that researchers have not yet tested for appendicularians.

Combining individual clearance rates estimates from Eq. (3) with oikopleurid population density and size distribution data permits calculation of their feeding impact on plankton populations. In the current study, calculations for 10 dates from July 1983 through July 1984 produced mean and maximum water column clearing rate estimates of 0.42 and $2.16 \% \mathrm{~d}^{-1}$ respectively (Table 4). Although low, these rates are of similar magnitude to those estimated for local copepod popu- lations (see below). Such low rates might suggest that oikopleurid feeding impact on phytoplankton populations in coastal Newfoundland waters would be minimal; however, much higher maximum densities of oikopleurids have previously been observed in Newfoundland coastal waters, ranging from maxima of ca $450 \mathrm{~m}^{-3}$ (Davis 1982, 1986) to over $2000 \mathrm{~m}^{-3}$ (Mahoney 1981, Mahoney \& Buggeln 1983). Our predictions of water column clearance rates for these higher densities, using tail lengths typical of the respective sampling periods, range up to $60 \%$ or more per day. These values can be compared collectively to those reported for warm waters where appendicularians have been estimated to consume typically less than $10 \%$ of their food population per day (reviewed in Alldredge 1984).

Knowledge of phytoplankton growth rates is also

Table 4. Oikopleura. Estimates of upper water column clearing rates due to grazing activity of the population based on density and size distribution of the animals and the total clearing rate:tail length relationship of Eq. (3)

\begin{tabular}{|c|c|c|c|c|}
\hline Date & $\begin{array}{l}\text { Density } \\
\text { (ind. } \mathrm{m}^{-3} \text { ) }\end{array}$ & $\begin{array}{l}\text { Individual } \\
\left(\mathrm{ml} \mathrm{d}^{-1}\right)\end{array}$ & $\begin{array}{l}\text { Clearing rates } \\
\text { Population } \\
\left(\mathrm{ml} \mathrm{m} \mathrm{m}^{-3} \mathrm{~d}^{-1}\right)\end{array}$ & $\begin{array}{c}\text { Water column } \\
\qquad\left(\% \mathrm{~d}^{-1}\right)\end{array}$ \\
\hline 7 Jul 1983 & 92.9 & 127.8 & 11870 & 1.19 \\
\hline 13 May 1984 & 1.1 & 476.3 & 519 & 0.05 \\
\hline 15 May 1984 & 53.0 & 407.1 & 21574 & 2.16 \\
\hline 18 May 1984 & 4.7 & 101.6 & 477 & 0.05 \\
\hline 20 May 1984 & 18.0 & 125.7 & 2256 & 0.23 \\
\hline 25 May 1984 & 36.3 & 74.3 & 2697 & 0.27 \\
\hline 31 May 1984 & 15.0 & 71.6 & 1070 & 0.11 \\
\hline 27 Jun 1984 & 8.6 & 58.3 & 498 & 0.05 \\
\hline 5 Jul 1984 & 1.7 & 158.2 & 271 & 0.03 \\
\hline $18 \mathrm{Jul} \quad 1984$ & 4.7 & 168.3 & 791 & 0.08 \\
\hline Mean & 23.6 & 176.9 & 4202 & 0.42 \\
\hline
\end{tabular}


necessary to fully evaluate the importance of oikopleurid grazing losses to phytoplankton population dynamics. Pauley (1987) has reported rates of nanoplankton numerical increase of 14 and $25 \% \mathrm{~d}^{-1}$ over $2 \mathrm{~d}$, in situ bag incubations during non-bloom and bloom periods respectively. Cryptophytes did not increase significantly in either experiment, however, suggesting that even low grazing losses could be significant to some components of the nanoplankton.

One way of evaluating the probable importance of oikopleurids to food chains is to compare their estimated water column clearing rates to those of the local copepod populations. An annual study of the zooplankton in nearby Conception Bay (Davis 1982) revealed that the calanoid copepods are dominated by Pseudocalanus sp. (cf. minutus) and Calanus finmarchicus while the cyclopoids are dominated by Oithona similis. We have combined copepod abundance and size data (Davis 1982, Davis pers. comm.) with estimates of individual clearing rates based on grazing studies of these species in the literature (Poulet 1974, 1977, 1978, Huntley 1981) to calculate estimated copepod community clearing rates for the upper $10 \mathrm{~m}$ of the water column (Table 5). Our calculations suggest that the copepod community clears an average of about $1.1 \%$ of the water column per day (10 $\left.944 \mathrm{ml} \mathrm{m} \mathrm{m}^{-3} \mathrm{~d}^{-1}\right)$. By comparison, the average Oikopleura density in Conception Bay was $113 \mathrm{~m}^{-3}$ (Davis pers. comm.). Multiplying this density by the median individual clearance rate for the dates reported in Table $4\left(123.2 \mathrm{ml} \mathrm{d}^{-1}\right)$, yields a water column clearing rate estimate of $1.4 \% \mathrm{~d}^{-1}$. This suggests that oikopleurids should play a trophic role of at least comparable importance to that of the copepods on an annual basis.

The importance of oikopleurids to fishery production in these waters remains open to speculation. Their large size and distinctive red coloration would seem to render them particularly susceptible to large, visually feeding planktivores such as juvenile fish; however, the absence of hard body-parts hinders their recognition in fish stomach-content analyses (Shelbourne 1962), and we are not aware of any data that would permit estimation of oikopleurid dietary significance to local fish populations. Shelbourne (1962) used the presence of fecal pellets of the small oikopleurid Oikopleura dioica in the stomachs of larval plaice in the North Sea to determine that they were the major diet item of the fish larvae.

Overall, our analyses indicate a reasonably strong relationship between total clearance rate and animal

Table 5. Estimated clearing rates of the dominant copepod species based on mean annual population abundance and size data for the upper $10 \mathrm{~m}$ of Conception Bay, Newfoundland (Davis 1982, Davis pers. comm.) and individual clearing rates calculated from studies of feeding by these species (see footnotes)

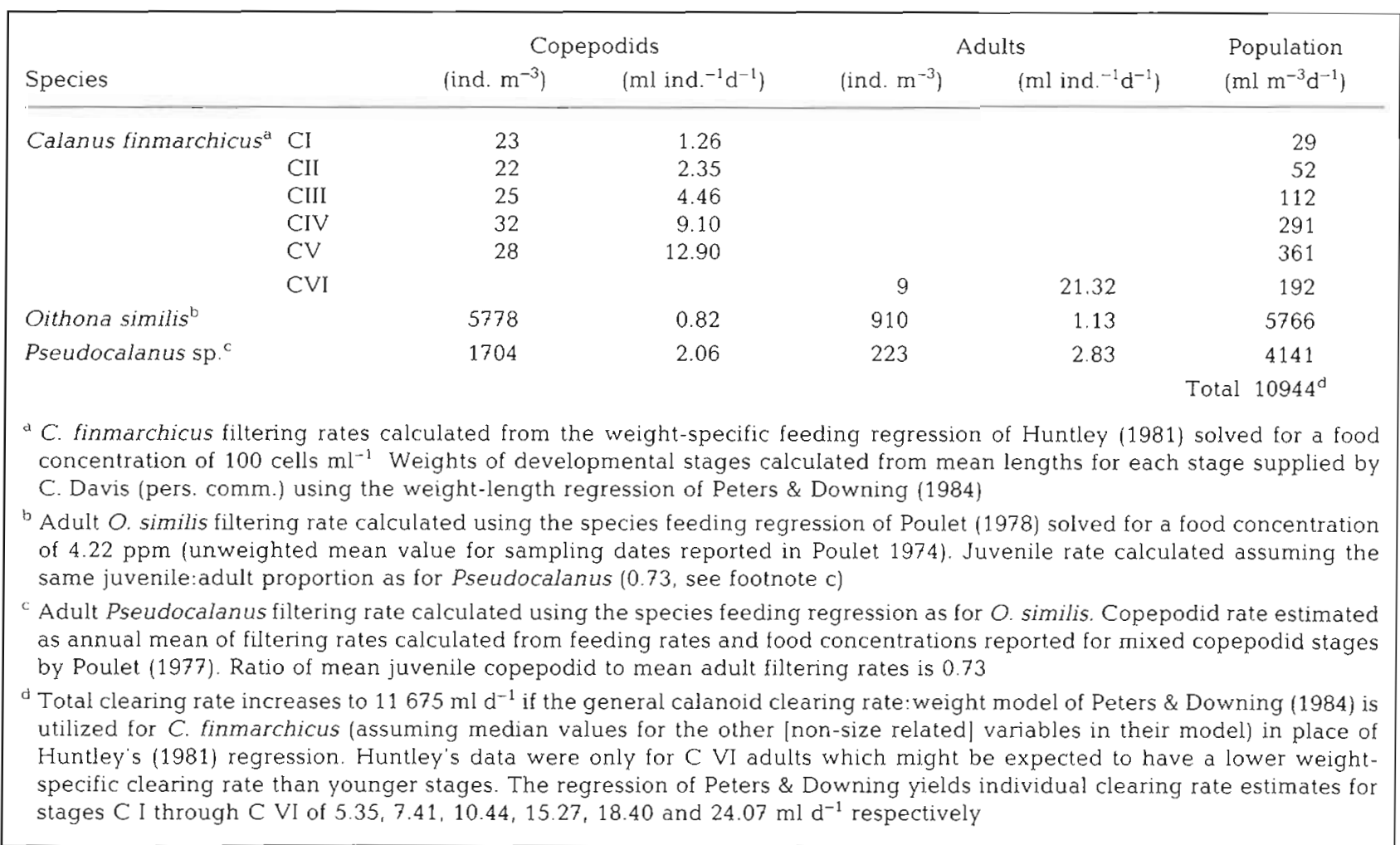


size which is modified by the abundance of very small and very large plankton and is relatively little affected by temperature. The relationships we have modelled herein permit estimation of water column clearance rates from basic population size and abundance data. These estimates should be of utility in estimating the impact of oikopleurids on their prey populations and in estimating their potential contribution to the flow of energy and matter to higher trophic levels. Further reductions in unexplained variance await insight into additional factors affecting animal activity and/or refinement of basic methodology. Such reductions in unexplained variance should not change the basic, underlying relationships we have observed; only the scatter should be reduced.

Acknowledgements. This research was supported by a Memorial University Graduate Fellowship (D. S. F.) and a Natural Sciences and Engineering Research Council of Canada operating grant (R.K.). We gratefully acknowledge the advice and assistance of the diving unit at the Marine Sciences Research laboratory and the photographic expertise of $\mathrm{R}$. Hooper who provided Fig. 1 C. C. Davis kindly provided additional unpublished details regarding the Conception Bay zooplankton population. We thank D. Deibel for helpful comments on an early draft of the manuscript.

\section{LITERATURE CITED}

Alldredge, A. (1975). Quantitative natural history and ecology of appendicularians and discarded appendicularian houses. Ph. D. thesis, Univ. California, Davis

Alldredge, A. (1976). Field behavior and adaptive strategies of appendicularians (Chordata: Tunicata). Mar. Biol. 38: 29-39

Alldredge, A. (1977). House morphology and mechanisms of feeding in the Oikopleuridae (Tunicata, Appendicularia). J. Zool., Lond. 181: 175-188

Alldredge, A. (1981). The impact of appendicularian grazing on natural food concentration in situ. Limnol. Oceanogr 26: $247-257$

Alldredge, A. (1984). The quantitative signficance of gelatinous zooplankton as pelagic consumers. In: Fasham, M. J. (ed.) Flows of energy and materials in marine ecosystems: theory and practice. Plenum Press, New York, p. 407-453

Davis, C. C. (1982). A preliminary quantitative study of the zooplankton from Conception Bay, Insular Newfoundland, Canada. Int. Revue ges. Hydrobiol, 67: 713-747

Davis, C. C. (1986). A comparison of the zooplankton in two Newfoundland bays with differing influences from major currents. Int. Revue ges. Hydrobiol. 71 : 11-47

Deibel, D. (1986). Feeding mechanism and house of the appendicularian Oikopleura vanhoeffeni. Mar. Biol. 93: 429-436

Deibel, D., Dickson, M.-L., Powell, C. V. L. (1985). Ultrastructure of the mucous feeding filter of the house of the appendicularian Oikopleura vanhoeffeni. Mar. Ecol. Prog. Ser. 27: 79-86

Deibel, D., Turner, J. T (1985). Zooplankton feeding ecology: contents of fecal pellets of the appendicularian 0 . vanhoeffeni (Lohmann). Mar. Ecol. Prog. Ser. 27: 67-78
Frost, B. W. (1972). Effects of size and concentrations of food particles on the feeding behavior of the marine planktonic copepod Calanus pacificus. Limnol. Oceanogr. 17 : $805-815$

Geller, W (1975). Die Nahrungsaufnahme von Daphnia pulex in Abhängigkeit von der Futterkonzentration, der Temperatur, der Körpergröße und dem Hungerzustand der Tiere. Arch. Hydrobiol. Suppl. 48: 47-107

Gow, J. A., Mills, F. H. J. (1984). Pragmatic criteria to distinguish psychrophiles and psychrotrophs in ecological systems. Appl. environ. Microbiol. 47: 213-215

Harbison, G. R., McAlister, V L. (1979). The filter-feeding rates and particle retention efficiencies of three species of Cyclosalpa (Tunicata, Thaliaceae). Limnol. Oceanogr. 24: $875-892$

Hartwig, F., Dearing, B. E. (1979). Exploratory data analysis. In: Sullivan, J. L. (ed.) Quantitative applications in the social sciences. Sage Publications, London, p. 1-83

Holtby, L. B., Knoechel, R. (1981). Zooplankton filtering rates: error due to loss of radioisotopic label in chemically pre. served samples. Limnol. Oceanogr. 26 (4): 774-780

Huntley, M. (1981). Nonselective, nonsaturated feeding by three calanid copepod species in the Labrador Sea. Limnol. Oceanogr. 26: 831-842

Kendaris, T. A. (1980). Physical and biological oceanographic observations in Logy Bay, Newfoundland: April-September 1979. Can. Ms. Rep. Fish. Aquat. Sci. 1569

King, K. R. (1981). The quantitative natural history of Oikopleura dioica (Urochorodata: Larvacea) in the laboratory and in enclosed water columns. Ph. D. thesis, Univ. Washington

Knoechel, R., Holtby, B. (1986). Construction and validation of a body-length-based model for the prediction of cladoceran community filtering rates. Limnol. Oceanogr. 31(1): $1-16$

Knoechel, R., Kalff, J. (1976). Track autoradiography: a method for the determination of phytoplankton species productivity. Limnol. Oceanogr. 21 (4): 590-596

Lohmann, H. (1899). Das Gehäuse der Appendicularien, sein Bau, seine Funktion und seine Entstehung. Schr naturwiss. Ver Schleswig-Holstein 11: 347-407

Mahoney, E. M. (1981). Observations on Oikopleura (Tunicata, Appendicularia) and the contribution of discarded larvacean houses to the slub problem in selected Newfoundland inshore locations. B. Sc. Hons. thesis, Memorial Univ. of Newfoundland

Mahoney, E. M., Buggeln, R. G. (1983). Seasonal variations in the concentration of Oikopleura spp. (Tunicata: Appendicularia) in Conception Bay, Newfoundland. Can. Tech. Rep. Fish. Aquat. Sci. 1155: 1-17

Nie, N. (1983). SPSS ${ }^{\times}$user's guide. McGraw-Hill Book Co., New York

Norusis, M. J. (1985). SPSS ${ }^{\times}$advanced statistics guide. McGraw-Hill Book Co., New York

Paffenhöfer, G. A. (1973). The cultivation of an appendicularian through numerous generations. Mar. Biol. 22: 183-185

Paffenhöfer, G. A. (1976). On the biology of appendicularia of the south eastern North Sea. In: Persoone, G., Jaspers, E. (eds.) 10th Eur. Mar. Biol. Symp., Ostend, Belgium, Vol. 2. Universa Press, Wetteren, p. 437-455

Pauley, K. E. (1987). Carbon uptake and turnover rates of phytoplankton in Newfoundland coastal waters. M. Sc. thesis, Memorial Univ. of Newfoundland

Peters, R. H, Downing, J. A. (1984), Empirical analysis of zooplankton filtering and feeding rates. Limnol. Oceanogr. 29: 763-784

Pomeroy, L. R., Deibel, D. (1986). Temperature regulation of 
bacterial activity during the spring bloom in Newfoundland coastal waters. Science 233: 359-361

Powell, J. C., Dabinett, P. E., Gow, J. A. (1987). An annual cycle of abundance and activity of heterotrophic bacteria and abundance of hydrocarbonoclastic bacteria in Newfoundland coastal water. Can. J. Microbiol. 33: 377-382

Poulet, S. A. (1974). Seasonal grazing of Pseudocalanus minutus on particles. Mar. Biol. 25: 109-123

Poulet, S. A. (1977). Grazing of marine copepod developmental stages on naturally occurring particles. J. Fish. Res. Bd Can. 34: 2381-2387

Poulet, S. A. (1978). Comparison between five coexisting species of marine copepods feeding on naturally occurring particulate matter. Limnol. Oceanogr. 23: 1126-1143

This article was presented by Professor G.-A. Paffenhöfer, Savannah, Georgia, USA
Shelbourne, J. E. (1962). A predator-prey size relationship for plaice larvae feeding on Oikopleura. J. mar biol. Ass. U. K. 42: $243-252$

Strathmann, R. R. (1967). Estimating the organic carbon content of phytoplankton from cell volume or plasma volume. Limnol. Oceanogr. 12: 411-418

Templeman, W. (1966). Marine resources of Newfoundland Bull. Fish. Res. Bd Can. 154: 1-170

Thompson, H., Frost, N. (1936). Hydrographic and biological investigations. Rep. Newfoundld. Fish. Res. Comm. 2 (3): $19-23$

Udvardy, M. D. (1954). Distribution of appendicularians in relation to the Strait of Belle Isle. J. Fish. Res. Bd Can. 11 (4): $431-448$

Manuscript first received: August 11, 1987

Revised version accepted: December 29, 1988 